\title{
BMJ open Screening for hypothalamic-pituitary- adrenal axis suppression in asthmatic children remains problematic: a cross-sectional study
}

\author{
Ekkehard Werner Zöllner, ${ }^{1,2}$ Carl J Lombard, ${ }^{3}$ Ushma Galal, ${ }^{3}$ Stephen Hough, ${ }^{4}$ \\ Elvis M Irusen, ${ }^{5}$ Eugene Weinberg ${ }^{6}$
}

To cite: Zöllner EW, Lombard CJ, Galal U, et al. Screening for hypothalamicpituitary-adrenal axis suppression in asthmatic children remains problematic: a cross-sectional study. BMJ Open 2013;3:e002935. doi:10.1136/bmjopen-2013002935

- Prepublication history and additional material for this paper is available online. To view these files please visit the journal online (http://dx.doi.org/10.1136/ bmjopen-2013-002935).

Received 22 March 2013 Revised 28 June 2013 Accepted 3 July 2013

For numbered affiliations see end of article.

\section{Corresponding to} Dr Ekkehard Werner Zöllner; zollner@sun.ac.za

\section{ABSTRACT}

Objective: To determine which parameter is the most useful screening test for hypothalamic-pituitaryadrenal suppression in asthmatic children.

Design: Cross-sectional study.

Setting: Paediatric allergy clinics in Cape Town, South Africa.

Participants: 143 asthmatic children of mostly mixed ancestry, aged $5-12$ years.

Outcome measures: Primary outcome measures included Spearman correlation coefficients ( $r$ ) calculated between the postmetyrapone (PMTP) serum adrenocorticotropic hormone (ACTH), 11-deoxycortisol (11DOC), 11DOC+ cortisol (C) and height, weight, height velocity, weight velocity, change in systolic blood pressure from supine to standing, early morning urinary free cortisol (UFC), morning C, ACTH and dehydroepiandrosterone sulfate (DHEAS). Secondary outcome measures were the receiver operating characteristics (ROC) curve and the diagnostic statistics for the most promising test.

Results: All screening variables were weakly correlated with the three PMTP outcomes. Only DHEAS and UFC $\left(\mathrm{nmol} / \mathrm{m}^{2}\right)$ were statistically significant-DHEAS for PMTP ACTH and 11DOC ( $r=0.20, p=0.025$ and $r=0.21$, $p=0.017)$; UFC $\left(\mathrm{nmol} / \mathrm{m}^{2}\right)$ for PMTP 11DOC and $11 D 0 C+C(r=0.19, p=0.033$ and $r=0.20, p=0.022)$. The area under ROC curve for DHEAS in the 5-year to 9-year age group was 0.69 ( $95 \% \mathrm{Cl} 0.47$ to 0.92$)$. At DHEAS cut-off of $0.2 \mu \mathrm{mol} / \mathrm{L}$ : sensitivity $=0.88$ (Cl 0.47 to 1.00 ), specificity $=0.61$ ( $\mathrm{Cl} 0.42$ to 0.78 ), positive predictive value $=0.37$ ( $\mathrm{Cl} 0.16$ to 0.62 ), negative predictive value $=0.95(\mathrm{Cl} 0.75$ to 1.00$)$, accuracy $=0.67(\mathrm{Cl} 0.50$ to 0.81 ), positive likelihood ratio=2.26 ( $\mathrm{Cl} 1.35$ to 3.78 ), negative likelihood ratio $=0.20$ ( $\mathrm{Cl} 0.03$ to 1.30 ).

Conclusions: No parameter is useful as a universal screening test. DHEAS may be suitable to exclude HPAS before adrenarche. Further research is needed to confirm these findings and identify factors, for example, genetic that may predict or protect against HPAS.

\section{INTRODUCTION}

Recently, two-thirds of asthmatic children treated with corticosteroids (CS) in allergy

\section{ARTICLE SUMMARY}

\section{Article focus}

- Two-thirds of asthmatic children treated with corticosteroids (CS) in allergy units in Cape Town, South Africa were found to have a degree of hypothalamic-pituitary-adrenal axis (HPA) dysfunction, while the pituitary/hypothalamus and the adrenals were suppressed in $16 \%$ of cases.

- It has been claimed that static adrenal function tests such as serum cortisol, adrenocorticotropic hormone (ACTH), dehydroepiandrosterone sulfate (DHEAS) and urinary free cortisol (UFC) are useful to document HPA suppression (HPAS) in asthmatic children on CS.

- This study was performed to detect the most suitable screening test by comparing several clinical and biochemical candidate tests with the overnight metyrapone test.

Key messages

- No clinical or static biochemical parameter is a universally useful screening test for HPAS in asthmatic children of all ages.

- Serum DHEAS may be of limited use prior to adrenarche.

Strengths and limitations of this study

- To the best of our knowledge, this is the largest study ever which analyses the usefulness of various candidate screening tests for HPAS.

- Contrary to common belief, it highlights the limited utility of UFC and DHEAS, both of which are frequently claimed to be helpful in detecting HPAS.

- As the study was powered to establish the diagnostic performance of the early morning serum ACTH, age-specific subgroups for an appropriate DHEAS analysis were rather small, thus limiting the usefulness of the latter analysis.

units in South Africa were found to have a degree of hypothalamic-pituitary-adrenal (HPA) axis dysfunction, while the pituitary/ 
hypothalamus and the adrenals were suppressed in only $16 \%$ of cases. ${ }^{1}$ Clinical features suggestive of adrenal insufficiency (AI) were only seen in some hypocortisolaemic children. This confirms the notion that HPA suppression (HPAS) is largely subclinical. ${ }^{2}$ In the allergy clinic setting, it is rather cumbersome and impractical to detect these by dynamic adrenal function tests. A suitable screening test should thus be sought. To qualify, strict criteria pertaining to the potential candidate, the disease and the intervention policy should be fulfilled. ${ }^{34}$ The latter two requirements are easily met. ${ }^{5}$ Whether a simple, safe, valid and reliable screening test with an appropriate cut-off can be found is another matter. Proposed clinical candidates such as height velocity (HV), or basal adrenal function tests, for example, dehydroepiandrosterone sulfate (DHEAS), urinary free cortisol (UFC) or urinary cortisol metabolites, whether as $24 \mathrm{~h}$, spot or early morning urine collection, have been investigated and found to be unsatisfactory. ${ }^{5}$ The theoretical limitations of the latter have previously been discussed in detail. ${ }^{2}$ Yet, conclusive remarks about HPA function are still based on static biochemical parameters in numerous clinical trials. ${ }^{6-10}$ The early morning adrenocorticotropic hormone (ACTH) has been identified as a possible useful screening test in a recent pilot study. ${ }^{5}$ However, ACTH's short plasma half life $(<10 \mathrm{~min})$ should have rendered it unsuitable. ${ }^{11}$ The area (AUC) under the receiver operating characteristics (ROC) curve for the morning serum ACTH, when compared to the overnight metyrapone test (ONMTPT) was 0.83 (95\% CI 0.65 to 1.00)), classifying it as a good test. Its utility, however, has to be confirmed, as the sample size was small $(\mathrm{n}=26)$. A larger cross-sectional study, including children with and without HPAS, was thus undertaken to determine which clinical or static biochemical parameter is the most useful screening test for HPAS in this setting.

\section{PARTICIPANTS AND METHODS}

A total of 143 asthmatic children, on inhaled CS (ICS) with or without additional CS therapy, were recruited from the allergy clinics of Tygerberg Children's Hospital, Red Cross Children's Hospital and the Lung Institute. Every eligible patient $\geq 11$ years and every second eligible patient $<11$ years was included. Asthma was diagnosed clinically by a doctor, based on symptoms and reversible airway obstruction. ${ }^{12}$ All children had persistent asthma, and those who were known to have HPA dysfunction, untreated hypothyroidism or liver disease and who were treated with phenobarbitone, phenytoin, rifampicin, amytryptyline, chlorpromazine, neomercazole or hormone replacement therapy were excluded. Height, weight and change in systolic blood pressure, as measured with an electronic blood pressure measuring device by the research assistant, were recorded. The annualised $\mathrm{HV}$ and weight velocity (WV) were calculated by extracting the height and weight data of 1 year earlier from the records. The following growth standards were utilised: the UK 1990 weight and height standards, the UK 1966 HV standards and the Gerver $2001 \mathrm{WV}$ standards. Anthropometric measurements and velocities were recorded as SD scores (SDS). The first voided early morning urine (06:00-07:00 h) for UFC was collected. The results were expressed both in $\mathrm{nmol} / \mathrm{m}^{2}$ body surface area and in nmol $/ \mathrm{mmol}$ creatine $(\mathrm{Cr})$. Fasting blood between 08:00 and 09:00 for cortisol (C), ACTH and dehydroepiandrosterone sulfate (DHEAS) was taken. The ONMTPT was performed according to published protocol, ${ }^{13}$ if the fasting morning serum $\mathrm{C}$ was $>83 \mathrm{nmol} / \mathrm{L}$. The rationale for its use and the cut-offs have been explained previously. ${ }^{12}$ An adequate response was defined by a rise of ACTH from baseline to $>106 \mathrm{pg} / \mathrm{mL} \quad(23.3 \mathrm{pmol} / \mathrm{L}),{ }^{14}$ an 11-deoxycortisol (11DOC) rise to $>208 \mathrm{nmol} / \mathrm{L}^{15}$ or a $11 \mathrm{DOC}+\mathrm{C}$ rise to $>400 \mathrm{nmol} / \mathrm{L} .{ }^{15} 16$ The ONMTPT was not performed on all participants, as the risk of precipitating an adrenal crisis during the performance of test is higher when the child is already hypocortisolaemic. Furthermore, frank hypocortisolaemia, implying that basal $\mathrm{C}$ production is impaired, would render dynamic testing superfluous. As the assays used in this study were different from the assays in the original description, the published cut-offs were modified by correlation studies, performed either in-house (11DOC) or by the manufacturer (ACTH). The readers of the tests were blind to all other results. The study was approved by the ethics committees of both universities. The investigators complied with the World Medical Association Declaration of Helsinki regarding ethical conduct of research involving human subjects. The study was funded by the Medical Research Council, the University of Stellenbosch, the South African Thoracic Society, the Harry Crossley Foundation and Red Cross Children's Hospital. No additional information is available.

\section{Assays}

Serum C and UFC was measured with the ADVIA automated chemiluminescent assay. The analytical sensitivity was $5.5 \mathrm{nmol} / \mathrm{L}$. At $107.05 \mathrm{nmol} / \mathrm{L}$ the intra-assay $\mathrm{CV}$ was $3.69 \%$ while the inter-assay CV was $5.45 \%$. No crossreactivity to fluticasone, budesonide, beclomethasone or prednisone is known. ACTH was measured with an automated sequential chemiluminescent immunometric assay (Immulite 2000). Its analytical sensitivity was $5 \mathrm{pg} / \mathrm{mL}$ $(1.1 \mathrm{pmol} / \mathrm{L})$, while the precision at $23 \mathrm{pg} / \mathrm{mL}(5 \mathrm{pmol} / \mathrm{L})$ ranged from $8.7 \%$ (within run) to $10 \%$ (run-to-run). No cross-reactivity has been reported. At the end of the study, levels of serum 11DOC were established by a single experienced person, utilising the Biosource competitive radioimmunoassay. Its analytical sensitivity was $0.1 \mathrm{nmol} / \mathrm{L}$. Only $0.1 \%$ cross-reactivity with $\mathrm{C}$ has been reported. The intra-assay $\mathrm{CV}$ at $82 \mathrm{nmol} / \mathrm{L}$ was $7.8 \%$ and the inter-assay $\mathrm{CV}$ at $95 \mathrm{nmol} / \mathrm{L}$ was $14.1 \%$. DHEAS levels were determined by an automated electrochemiluminescence immunoassay (Modular Analytics E170) with an 
analytical sensitivity of $0.003 \mu \mathrm{mol} / \mathrm{L}$. The lower limit of the analyser was set at $0.1 \mu \mathrm{mol} / \mathrm{L}$. At a mean of $2.6 \mu \mathrm{mol} / \mathrm{L}$ the intra-assay $\mathrm{CV}$ was $3.2 \%$, while the interassay CV was $2.5 \%$ at a mean $2.5 \mu \mathrm{mol} / \mathrm{L}$. The CVs were $2.6 \%$ and $2.7 \%$, respectively, for means of 10.9 $10.7 \mu \mathrm{mol} / \mathrm{L}$. There was no significant cross-reactivity.

\section{Statistical analysis}

On the basis of a pilot study $(\mathrm{n}=26)$, a sample size of 100 was calculated to be sufficient to halve the CI of 0.57 to 0.98 for the sensitivity $(0.89)$ of the morning ACTH. Growth velocities were analysed by Growth Analyser, V.3.5. Spearman correlations ( $r$ ) were calculated between the postmetyrapone (PMTP) ACTH, 11DOC, 11DOC+C and each proposed screening variable. Based on the most significant Spearman correlations, ROC analysis was performed. Using the probit model and maximum likelihood estimation, a parametric ROC regression analysis of DHEAS screening on HPAS was carried out and two covariates, age and sex, were adjusted for. The effect sizes from the ROC regression model can be interpreted as the standardised linear effects of the covariates on HPAS. ROC curves were drawn for the best model and the sensitivity, specificity, positive/negative predictive values, accuracy, positive and negative likelihood ratios (LRs) were calculated for the optimal cut-off between sensitivity and specificity. Analyses were carried out in STATA and $\mathrm{R},{ }^{17}$ the freely available environment for graphics and statistics. The score method was used to calculate the CIs of the LRs.

\section{RESULTS}

The study ran from July 2008 until June 2010 (tables 1 and 2). The ONMTPT was performed 2-3 weeks after the morning samples were obtained. Asthma therapy remained the same during this period, except in two cases which were excluded. ONMTP was repeated in two patients who vomited after administration of MTP.

During the analysis, outliers were not excluded, but participants with missing values were. After adjusting for age, using ANOVA, no centre difference on log ACTH $(\mathrm{p}=0.105)$ and $\log ($ DHEAS +0.22$) \quad(\mathrm{p}=0.543)$ could be demonstrated.

The prevalence of HPAS was previously reported. ${ }^{1}$ Only serum DHEAS and UFC $\left(\mathrm{nmol} / \mathrm{m}^{2}\right)$ were statistical significantly correlated with the postmetyrapone (PMTP) ACTH, 11DOC and 11DOC+C (table 3). As normal DHEAS values are known to vary with age and gender, further analysis of DHEAS measurements were carried out for the same subgroups in which normal values had been established by Roche (table 4). A ROC regression analysis of DHEAS revealed a significant age and sex effect on HPAS. The effect sizes for age were $-1.62(\mathrm{p}=0.006)$ for the 10-year-old to 14-year-old children and-3.59 $\quad(\mathrm{p}<0.001)$ for the 15-year-old to 19-year-old children. This implies that these age groups make a negative contribution to the ROC curve. The

\begin{tabular}{|c|c|}
\hline Total $\mathrm{n}$ & 143 \\
\hline Male:female & $77: 66$ \\
\hline Age (range) & $11^{*}(5.2-17.5)$ years \\
\hline Ethnic group & $\begin{array}{l}\text { Mixed ancestry } 138 \\
\text { Caucasian } 4 \\
\text { African } 1\end{array}$ \\
\hline Asthma score $†$ & $1.43^{*}(0.14-4.14)$ \\
\hline ICS and device & $\begin{array}{l}\text { BUD Hfa MDI and spacer } 128 \\
\text { BUD Hfa MDI } 11 \\
\text { BUD Hfa vMDI } 1 \\
\text { FP DPI } 3\end{array}$ \\
\hline $\begin{array}{l}\text { Daily ICS dose } / \mathrm{m}^{2} \\
\text { (range) }\end{array}$ & $\begin{array}{l}\text { BUD equivalent } 439^{\star}(108-1058) \mu \mathrm{g} \\
\mathrm{HC} \text { equivalent } 5.5^{\star}(1.3-13.2) \mathrm{mg}\end{array}$ \\
\hline $\begin{array}{l}\text { Duration of ICS } \\
\text { therapy (range) }\end{array}$ & $41^{*}(2-157)$ months \\
\hline $\begin{array}{l}n \text { on NS } \\
\text { (\% of total) }\end{array}$ & $122 / 143(85)$ \\
\hline NS & $\begin{array}{l}\text { BDP } 118 \\
\text { BUD } 4\end{array}$ \\
\hline $\begin{array}{l}\text { Daily NS dose } / \mathrm{m}^{2} \\
\text { (range) }\end{array}$ & $\begin{array}{l}\text { BUD equivalent } 118^{*}(54-468) \mu \mathrm{g} \\
\mathrm{HC} \text { equivalent } 1.5^{\star}(0.7-5.9) \mathrm{mg}\end{array}$ \\
\hline $\begin{array}{l}\text { Duration of NS } \\
\text { therapy (range) }\end{array}$ & $36^{*}(2-136)$ months \\
\hline $\begin{array}{l}n \text { on OCS } \\
\text { (\% of total) }\end{array}$ & $5 / 143(3)$ \\
\hline $\begin{array}{l}\text { Daily OCS dose } / \mathrm{m}^{2} \\
\text { (range) } \\
\mathrm{n} \text { on TS } \\
\text { (\% of total) }\end{array}$ & $\begin{array}{l}\text { HC equivalent§ } 125.5^{*} \\
(17.5-187.3) \mathrm{mg} \\
60 / 143(42)\end{array}$ \\
\hline TS & $\begin{array}{l}\text { Fluocinolone, betamethasone, } \\
\text { methylprednisolone aceponate, } \\
\text { hydrocortisone }\end{array}$ \\
\hline $\begin{array}{l}\text { Duration of TS } \\
\text { therapy (range) }\end{array}$ & $30^{*}(0.25-356)$ months \\
\hline $\begin{array}{l}\mathrm{n} \text { on steroid eye } \\
\text { drops (\% of total) }\end{array}$ & 4/143 (3) \\
\hline Steroid eye drops & $\begin{array}{l}\text { Fluoromethalone } 3 \\
\text { Dexamethasone } 1 \\
\end{array}$ \\
\hline \multicolumn{2}{|c|}{$\begin{array}{l}\text { *Median. } \\
\text { †As established by Asthma Control Questionnaire. } \\
\text { †80 } \mathrm{\mu g} \text { BUD is comparable to } 1 \mathrm{mg} \text { HC in potency. } \\
\$ 1 \mathrm{mg} \text { prednisone equates to } 4 \mathrm{mg} \mathrm{HC} \text { in potency. } \\
\text { BUD, budesonide; BDP, Beclomethasone diproprionate; DPI, dry } \\
\text { powder inhaler; FP, fluticasone proprionate; HFA, } \\
\text { hydrofluroalkane; HC, hydrocortisone; ICS, inhaled corticosteroids; } \\
\text { MDI, metered dose inhaler; NS, Nasal steroids; OCS, oral } \\
\text { corticosteroids (prednisone given for maintenance or } \\
\text { exacerbation (ONMTPT performed while on OCS); TS, topical } \\
\text { steroids. }\end{array}$} \\
\hline
\end{tabular}

effect size for gender was $1.19(\mathrm{p}=0.024)$, implying that gender makes a positive contribution to the ROC curve. As the subgroups of the study were rather small and as it is known that the normal reference range of DHEAS prior to onset of adrenarche is the same for boys and girls, the gender categories were pooled to obtain a larger sample per age group. The derived smoothed ROC curves showed a clear separation between the age groups, confirming the age effect (figure 1). The AUC for the crude ROC curve of the only promising age group, the 5-year-olds to 9-year-olds, was 0.69 (CI 0.47 to 
Table 2 Number of subjects available for analysis with each individual test

\begin{tabular}{|c|c|c|}
\hline Test & $\begin{array}{l}\text { n Available for } \\
\text { analysis (\%) }\end{array}$ & $\begin{array}{l}\text { Reason for } \\
\text { exclusion }\end{array}$ \\
\hline \multicolumn{3}{|l|}{ Gold standard } \\
\hline PMTP & \multirow[t]{2}{*}{ 133/143 (93.0) } & \multirow{6}{*}{$\begin{array}{l}\text { Inadequate sample } \\
\text { handling } \\
\text { Inadequate serum } \\
\text { volume } \\
\text { Inadequate serum } \\
\text { volume }\end{array}$} \\
\hline $\mathrm{ACTH}$ & & \\
\hline PMTP & \multirow[t]{2}{*}{$135 / 143(94.4)$} & \\
\hline 11DOC & & \\
\hline PMTP & \multirow[t]{2}{*}{ 129/143 (90.2) } & \\
\hline $11 \mathrm{DOC}+\mathrm{C}$ & & \\
\hline \multicolumn{3}{|c|}{ Screening variables } \\
\hline Height SDS & \multicolumn{2}{|l|}{$143 / 143(100)$} \\
\hline Weight & \multirow{2}{*}{\multicolumn{2}{|c|}{$143 / 143(100)$}} \\
\hline SDS & & \\
\hline HV SDS & 132/143 (92.3) & Missing data \\
\hline WV SDS & 139/143 (97.2) & Missing data \\
\hline$\Delta \mathrm{SBP}$ & 142/143 (99.3) & $\begin{array}{l}\text { Missing } \\
\text { measurement }\end{array}$ \\
\hline Morning & \multirow{2}{*}{\multicolumn{2}{|c|}{$143 / 143(100.0)$}} \\
\hline ACTH & & \\
\hline Morning C & 142/143 (99.3) & Transcription error \\
\hline UFC & $128 / 143(89.5)$ & $\begin{array}{l}\text { Samples leaked in } \\
\text { transit }\end{array}$ \\
\hline DHEAS & $127 / 143(88.8)$ & $\begin{array}{l}\text { Samples stored } \\
>2 \text { months }\end{array}$ \\
\hline
\end{tabular}

ACTH, adrenocorticotropic hormone; C, Cortisol; DHEAS, dehydroepiandrosterone sulfate; HV, height velocity; PMTP, postmetyrapone; 11DOC, 11-Deoxycortisol; $\triangle \mathrm{SBP}$, change in systolic blood pressure; UFC, urinary free cortisol; WV, weight velocity.

0.92; figure 2). The best discrimination between those with HPAS (sensitivity of 0.88 ) and those without HPAS (specificity of 0.61 ) for this age group is a DHEAS value of $0.2 \mu \mathrm{mol} / \mathrm{L}$. The diagnostic performance at this point is given in table 5 .

The AUC for the ROC curve of the UFC $\left(\mathrm{nmol} / \mathrm{m}^{2}\right)$ compared to the PMTP 11DOC was only 0.57 (CI 0.47 to 0.67 ). This improved slightly to 0.63 (CI 0.53 to 0.72 ) when the outcome of the gold standard test was changed to the PMTP 11DOC+C. Adding DHEAS and UFC $\left(\mathrm{nmol} / \mathrm{m}^{2}\right)$ to a logistic regression model for HPAS, previously described, ${ }^{1}$ did not improve the model. The OR for DHEAS and UFC $\left(\mathrm{nmol} / \mathrm{m}^{2}\right)$ were 0.72 (CI 0.33 to 1.26 ) and 1.00 (CI 0.99 to 1.01 ) respectively.

\section{DISCUSSION}

The results of the pilot study $(n=26)^{5}$ in which the early morning serum ACTH was moderately and significantly correlated $(r=0.68 ; \mathrm{p}<0.001)$ to the PMTP ACTH, could not be confirmed in the present study. This may be the result of studying a larger sample $(n=143)$ with increased heterogeneity. As explained above, a single serum ACTH level is unlikely to be a valid indicator of HPAS $^{11}$ and hence does not fulfil the criteria for a screening test. ${ }^{3}{ }^{4}$ A valid screen should be able to distinguish between patients who do and those who do not have HPAS. "Furthermore, it should be cost-effective, easy to perform, safe, reliable and the cut-off value between pathology and normality should be reasonably well defined." As indicated by significant Spearman correlations, it is only the serum DHEAS and UFC (nmol/ $\mathrm{m}^{2}$ ) that need further consideration as screening tests.

It is clear from the ROC regression model that serum DHEAS is not a useful screening tool in the 10-14 and the 15-year to 18-year age groups. The AUC of the ROC curve for the 5-year-olds to 9-year-olds is similar to the one published recently, ${ }^{6}$ although in the latter, a subgroup analysis was not performed. At best it is a fair screening test in the younger age group. The pretest probability (prevalence) of HPAS is known to be $16 \%{ }^{1}$ At a diagnostic cut-off of $0.2 \mu \mathrm{mol} / \mathrm{L}$, the post-test probability, given a lower DHEAS level, would rise to $30 \%$ (CI 21 to $42 \%$ ) if the serum DHEAS is utilised as a screening test (refer to the positive LR in table 4). With a DHEAS measurement above $0.2 \mu \mathrm{mol} / \mathrm{L}$ (see negative LR in table 4), the post-test probability would drop to

Table 3 Spearman correlations between PMTP ACTH, 11DOC, 11DOC $+\mathrm{C}$ and screening variables

\begin{tabular}{|c|c|c|c|c|c|c|}
\hline \multirow[b]{2}{*}{ Screening variable } & \multicolumn{2}{|l|}{ АCTH } & \multicolumn{2}{|c|}{ 11DOC } & \multicolumn{2}{|c|}{ 11DOC+C } \\
\hline & $\bar{r}$ & p Value & $\bar{r}$ & $\overline{p \text { Value }}$ & $\bar{r}$ & p Value \\
\hline Height SDS & 0.12 & 0.186 & -0.13 & 0.120 & -0.05 & 0.542 \\
\hline Weight SDS & 0.10 & 0.262 & -0.01 & 0.195 & -0.10 & 0.279 \\
\hline HV SDS & 0.00 & 0.999 & 0.07 & 0.420 & 0.07 & 0.452 \\
\hline WV SDS & -0.04 & 0.638 & 0.07 & 0.421 & 0.09 & 0.302 \\
\hline$\Delta \mathrm{SBP}$ & 0.00 & 0.992 & 0.05 & 0.538 & -0.04 & 0.616 \\
\hline Morning C & 0.05 & 0.538 & 0.08 & 0.374 & 0.12 & 0.176 \\
\hline Morning ACTH & 0.10 & 0.248 & 0.04 & 0.640 & 0.10 & 0.263 \\
\hline DHEAS & 0.20 & $0.025^{\star}$ & 0.21 & $0.017^{*}$ & 0.00 & 0.995 \\
\hline UFC $\left(\mathrm{nmol} / \mathrm{m}^{2}\right)$ & 0.08 & 0.379 & 0.19 & $0.033^{*}$ & 0.20 & $0.022^{*}$ \\
\hline UFC (nmol/mmol Cr) & 0.08 & 0.397 & 0.14 & 0.111 & 0.16 & 0.064 \\
\hline
\end{tabular}

${ }^{*}$ Significant, $p<0.05$.

ACTH, adrenocorticotropic hormone; C, Cortisol; DHEAS, dehydroepiandrosterone sulphate; HV, height velocity; PMTP, post-metyrapone; $\triangle \mathrm{SBP}$, change in systolic blood pressure; UFC, urinary free cortisol; WV, weight velocity; 11DOC, 11-deoxycortisol. 
Table 4 HPAS $^{*}$, by age group and gender, with measured serum DHEAS

\begin{tabular}{lrrrr}
\hline & \multicolumn{4}{l}{ Age (years) } \\
\cline { 2 - 5 } Category & $\mathbf{5 - 9}$ & $\mathbf{1 0 - 1 4}$ & $\mathbf{1 5 - 1 8}$ & Total \\
\hline Males & & & & \\
No HPAS & 18 & 32 & 9 & 59 \\
HPAS & 2 & 6 & 2 & 10 \\
Total & 20 & 38 & 11 & 69 \\
Females & & & & \\
No HPAS & 14 & 25 & 9 & 48 \\
HPAS & 6 & 3 & 1 & 10 \\
Total & 20 & 28 & 10 & 58 \\
& & & & \\
Total & & & & \\
No HPAS & 32 & 57 & 18 & 107 \\
HPAS & 8 & 9 & 3 & 20 \\
Total & 40 & 66 & 21 & 127 \\
\hline
\end{tabular}

*Postmetyrapone ACTH $<106 \mathrm{p} / \mathrm{mL}$ (23.3 pmol/L) AND $11 \mathrm{DOC}<208 \mathrm{nmol} / \mathrm{L}$ AND $11 \mathrm{DOC}+\mathrm{C}<400 \mathrm{nmol} / \mathrm{L}$.

DHEAS, dehydroepiandrosterone sulphfate; HPAS, hypothalamicpituitary-adrenal suppression.

$3.7 \%$ (CI $0 \%$ to 20\%). Thus, serum DHEAS levels seem to be more useful in ruling out HPAS (see negative predictive value in table 4) than predicting it. A DHEAS level may hence not qualify as a useful screen, bearing in mind that this conclusion is based on a small sample size.

Serum DHEAS has repeatedly been touted in the literature as a useful screening tool for central $\mathrm{AI}^{18}{ }^{19}$ or for HPAS in asthmatics treated with ICS. ${ }^{6}{ }^{20-22}$ In one study, it was claimed that the serum DHEAS is a 'practical surrogate measurement' to identify asthmatic



Figure 1 Predicted ROC curves (from a ROC regression model) of DHEAS versus HPAS by age.

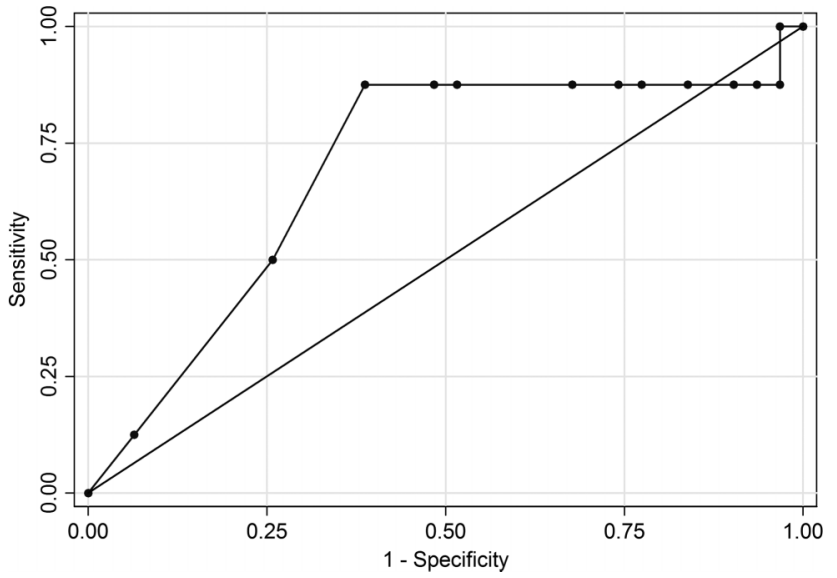

Figure 2 ROC curve of DHEAS versus HPAS for 5-9 year old age group. Area under ROC curve=0.69 (95\% Cl: 0.47-0.92).

children at risk of HPAS. ${ }^{6}$ However, only 22 patients of unknown age and gender were enrolled. DHEAS levels were not compared to a gold standard adrenal function test. Results were presented in SDS which is problematic, as normal DHEAS measurements do not follow a Gaussian distribution. The limitations of this study prompted us to look at the DHEAS performance in our study, even though it was not powered to do this. Clearly, even a sample of 40 in our 5-year to 9-year age group is too small for an optimal and conclusive study (table 4). Each subgroup would have required 50-100 children.

Whether one should embark on a larger study to ascertain the diagnostic capability of serum DHEAS in the 'pre-adrenarchal' age group, is debatable. Presumably, the cost and effort of such an undertaking do not outweigh the benefit. Clearly, serum DHEAS is not a useful screening test in the older paediatric age groups where normal levels are known to vary with age, gender and Tanner stage. ${ }^{23}$ There are similar limitations seen in adults with central AI, although it is claimed its accuracy is $100 \%$ in patients $<30$ years $(n=11)$, and, that it performs better in patients with pituitary macroadenomas $(n=31) .{ }^{18}$ In patients without pituitary adenomas $(n=35)$, the AUC of ROC curve was 0.71 -similar to the AUC established in this study.

Table 5 Diagnostic performance of DHEAS, at $0.2 \mu \mathrm{mol} /$ $\mathrm{L}$, for 5 -year-old to 9-year-old age group

\begin{tabular}{lll}
\hline Index of test validity & Value & $\mathbf{9 5 \%} \mathbf{C l}$ \\
\hline Sensitivity & 0.88 & 0.47 to 1.00 \\
Specificity & 0.61 & 0.42 to 0.78 \\
Positive predictive value & 0.37 & 0.16 to 0.62 \\
Negative predictive value & 0.95 & 0.75 to 1.00 \\
Accuracy & 0.67 & 0.50 to 0.81 \\
Positive likelihood ratio & 2.26 & 1.35 to 3.78 \\
Negative likelihood ratio & 0.20 & 0.03 to 1.30 \\
\hline DHEAS, dehydroepiandrosterone sulfate.
\end{tabular}


In adulthood, the average DHEAS levels are much higher (about $10 \mu \mathrm{mol} / \mathrm{L}$ ). ${ }^{24}$ Thus, determined by adult requirements, analysers have been calibrated at a lower limit which is higher than the analytical sensitivity of the assay. It is unlikely that large scale recalibrations will be performed outside the research setting in order to accommodate readings in the $\mathrm{nmol} / \mathrm{L}$ range for the 'pre-adrenarchal' age group ${ }^{13}$ thereby limiting its usefulness as a screening tool for this age. Furthermore, ACTH is not the sole stimulus of DHEAS release. Fragments of proopiomelanocortin, ${ }^{24}$ insulin-like growth factor one (IGF-1) and insulin ${ }^{25}$ also seem to be playing a role. DHEAS levels are therefore unsuitable candidates on theoretical grounds.

UFC is known to be useful in the setting of C excess, but not in $\mathrm{C}$ deficiency. Its usefulness as a screening test is limited by physiology and the design of the assay. ${ }^{2}{ }^{5}$ Under normal circumstances, most $\mathrm{C}$ is bound to cortisol binding globulin with only $<1 \%$ of free $\mathrm{C}$ being excreted in the urine, making it difficult to distinguish a $\mathrm{C}$ deficient from a $\mathrm{C}$ sufficient state. The proportion of free $\mathrm{C}$ in the urine rises substantially as the serum total $\mathrm{C}$ increases to $\geq 690 \mathrm{nmol} / \mathrm{L}$. One could argue that it would have been more appropriate to collect a $24 \mathrm{~h}$ urine sample in order to correctly reflect the daily production of $\mathrm{C}$. This is, however, not the purpose of a screening test and would be impractical, especially in children. Furthermore, all the limitations would apply, irrespective of volume and duration of collection. We would thus not encourage the use of any screen based on UFC, as it is extremely unlikely to accurately predict which child will appropriately respond to stress.

We did not assess salivary free $\mathrm{C}$, because its limitations are similar to those of the UFC, its lower limit of normal being close to zero, making an assessment of HPAS difficult. ${ }^{2}$ Furthermore, salivary free C, like serum $\mathrm{C}$ and ACTH, is subjected to ultradian and circadian rhythms which could be modified by season, puberty, exercise and stresses. Like UFC, salivary free $\mathrm{C}$ is more useful in diagnosing Cushing's syndrome, by demonstrating loss of diurnal variability.

The route, mode or relative contribution of the various forms of inhibiting CS (table 1) is of no consequence in the quest for suitable screening tests for HPAS. Nonetheless, it has been established that, of the CS used, only ICS and nasal CS contributed significantly to the suppression. ${ }^{1}$ Oral CS courses for exacerbations did not correlate to HPAS. ${ }^{1}$

HPAS already occurred at combined ICS and nasal CS doses equivalent to the normal $\mathrm{C}$ production rate of $3-10.6 \mathrm{mg} / \mathrm{m}^{2} /$ day (equivalent to budesonide $240-$ $848 \mu \mathrm{g} / \mathrm{m}^{2} /$ day), thus challenging the perception that a fluticasone propionate dose of $<400 \mu \mathrm{g} /$ day (budesonide dose $<800 \mu \mathrm{g}$ /day), based on $12 \mathrm{~h} \mathrm{UFC}^{26}$ is less suppressive than at higher doses. ${ }^{1}$

Continuing the search for a suitable screening test to detect HPAS is at this point unlikely to be successful. One can only attempt to predict which asthmatic children on
CS are likely to develop HPAS. ${ }^{1}$ Alternatively, a search for mutations or gene polymorphisms which determine the interindividual variation at various levels of the HPA should be undertaken. ${ }^{27-30}$ This may provide the best way to predict which asthmatic child would be predisposed to or protected against HPAS.

\section{CONCLUSIONS}

No clinical or static biochemical parameter could be identified as a suitable screening test for HPAS in asthmatic children of all ages. Serum DHEAS levels may only be useful to rule out HPAS in children prior to adrenarche.

We therefore discourage the use of any basal adrenal function test. Any researcher who plans to utilise the serum DHEAS level as a screen in the 5-year-old to 9-year-old age group, needs to document its diagnostic performance in a large study first. Further research is needed to identify genetic factors that might predict or protect against HPAS.

\section{Author affiliations}

${ }^{1}$ Paediatric Endocrine Unit, Department of Paediatrics, Stellenbosch University, Tygerberg Children's Hospital, Cape Town, South Africa ${ }^{2}$ Endocrine Unit, Red Cross Children's Hospital, University of Cape Town, Cape Town, South Africa

${ }^{3}$ Biostatistics Unit, Medical Research Council, Cape Town, South Africa ${ }^{4}$ Division of Endocrinology, Department of Medicine, Tygerberg Hospital, Stellenbosch University, Cape Town, South Africa

${ }^{5}$ Pulmonology Division, Department of Medicine, Tygerberg Hospital, Stellenbosch University, Cape Town, South Africa

${ }^{6}$ Allergy Unit, Red Cross Children's Hospital, University of Cape Town, Cape Town, South Africa

Acknowledgements We would like to acknowledge the financial support of the Medical Research Council, the University of Stellenbosch, the SA Thoracic Society, the Harry Crossley Foundation and Red Cross Children's Hospital. We are indebted to Sisters Hill, Poggenpoel, Pontac, Steyn, their superiors (for allowing them to participate) as well as all paediatricians and medical officers at the various centres for recruitment of patients. We are grateful for the laboratory support provided by B Fenemore and the laboratories of Groote Schuur and Tygerberg Hospitals and the Bioanalytic Research Corporation. Finally, we are deeply indebted to Roche for supplying us with the raw data of their reference range finding study. Without this information, a proper and conclusive analysis of the DHEAS measurements would not have been possible.

Contributors EWZ has made substantial contribution to conception, design and acquisition of the data, analysis and interpretation of the data, drafted the article and revised it. He approved the final version of the manuscript to be published. CJL was involved in the design of the study, analysis and interpretation of the data, reviewed the article and approved the final version of the manuscript to be published. UG has performed the data analysis and contributed to the interpretation of the data, revised the article and approved the final version of the manuscript to be published. FS $\mathrm{H}$ made a fundamental intellectual contribution to said manuscript and approved publication of the attached version of the paper. EMI contributed to the conception and design of the study. He also made a contribution to analysis, interpretation and discussion of the data, approved the final version of the manuscript to be published. EGW has had intellectual input in this article and approved the final version of the manuscript to be published.

Funding Funded by the Medical Research Council, the University of Stellenbosch, the SA Thoracic Society, the Harry Crossley Foundation and Red Cross Children's Hospital. Grant numbers: No grant numbers provided. 
Competing interests None.

Ethics approval Ethics Committees of Stellenbosch University and University of Cape Town.

Provenance and peer review Not commissioned; externally peer reviewed.

Data sharing statement No additional data are available.

Open Access This is an Open Access article distributed in accordance with the Creative Commons Attribution Non Commercial (CC BY-NC 3.0) license, which permits others to distribute, remix, adapt, build upon this work noncommercially, and license their derivative works on different terms, provided the original work is properly cited and the use is non-commercial. See: http:// creativecommons.org/licenses/by-nc/3.0/

\section{REFERENCES}

1. Zöllner EW, Lombard C, Galal U, et al. Hypothalamic-piuitary-adrenal axis suppression in asthmatic school children. Pediatrics 2012;130:e1512-19.

2. Zöllner EW. Hypothalamic-piuitary-adrenal axis suppression in asthmatic children on inhaled corticosteroids: Part 1. Which test should be used? Pediatr Allergy Immunol 2007:18:401-9.

3. Grimes DA, Schulz KF. Uses and abuses of screening tests. Lancet 2002;359:881-4.

4. Hammond M, Gear J. Measuring community health. Workbook 1. Cape Town: Oxford University Press, 1986:299-334.

5. Zöllner EW, Lombard C, Galal U, et al.

Hypothalamic-pituitary-adrenal axis suppression in asthmatic children on inhaled and nasal corticosteroids: is the early-morning serum adrenocorticotropic hormone (ACTH) a useful screening test? Pediatr Allergy Immunol 2011;22:614-20.

6. Dorsey MJ, Cohen LE, Phipatanakul W, et al. Assessment of adrenal suppression in children with asthma treated with inhaled corticosteroids: use of dehydroepiandrosterone sulphate as a screening test. Ann Allergy Asthma Immunol 2006;97:182-6.

7. Kannisto $S$, Laatikainen A, Taivainen A, et al. Serum dehydroepiandrosterone sulfate as an indicator of adrenocortical suppression during inhaled steroid therapy in adult asthmatic patients. Eur J Endocrinol 2004;150:687-90.

8. Skoner DP, Meltzer EO, Milgrom $\mathrm{H}$, et al. Effects of inhaled mometasone furoate on growth velocity and adrenal function: a placebo-controlled trial in children 4-9 years old with mild persistent asthma. J Asthma 2011;48:848-59.

9. Allen A, Schenkenberger I, Trivedi R, et al. Inhaled fluticasone furoate/vilanterol does not affect hypothalamic-pituitary-adrenal axis function in adolescent and adult asthma; randomised, double-blind, placebo-controlled study. Clin Respir J Published ahead of print: 12 Apr 2013. doi:10.1111/crj.12026

10. Bleeker ER, Bateman ED, Busse WW, et al. Once-daily fluticasone furoate is efficacious in patients with symptomatic asthma on low-dose inhaled corticosteroids. Ann Allergy Asthma Immunol 2012:109:353-8.

11. Aaron DC. Diagnostic implications of adrenal physiology and clinica epidemiology for evaluation of glucocorticoid excess and deficiency. In: De Groot LJ, Jameson J, eds. Endocrinology. Vol 3. Philadelphia: WB Saunders Company, 2001:1655-70.
12. Motala C, Green RJ, Manjra Al, et al. Guideline for the management of chronic asthma in children-2009 update. S Afr Med J 2009;99:898-912.

13. Forest MG. Adrenal function tests. In: Ranke MB, ed. Diagnostics of endocrine function in children and adolescents. Basel: Karger, 2003:372-426.

14. Staub JJ, Noelpp B, Girard J, et al. The short metyrapone test: comparison of the plasma ACTH response to metyrapone and insulin-induced hypoglycaemia. Clin Endocrinol 1979;10:595-601.

15. Fiad TM, Kirby JM, Cunningham SK, et al. The overnight single-dose metyrapone test is a simple and reliable index of the hypothalamic-pituitary-adrenal axis. Clin Endocrinol 1994;40:603-9.

16. Berneis K, Staub JJ, Gessler A, et al. Combined stimulation of adrenocorticotropin and compound-s by single dose metyrapone test as an outpatient procedure to assess hypothalamic-pituitary-adrenal function. J Clin Endocrinol Metab 2002;87:5470-5.

17. R Core Team. R: A language and environment for statistical computing. Vienna, Austria: R Foundation for Statistical Computing, 2012. http://www.R-project.org/ (accessed Oct 2012).

18. Fischli S, Jenni S, Allermann S, et al. Dehydroepiandrosterone sulfate in the assessment of the hypothalamic-pituitary-adrenal axis. $J$ Clin Endocrinol Metab 2008:93:539-42.

19. Nasraallah MP, Arafah BM. The value of dehydroandrosterone sulphate measurements in the assessment of adrenal function. $J$ Clin Endocrinol Metab 2003;88:5293-8.

20. Yamaji T, Ishibashi M, Takaku F, et al. Serum dehydroepiandrosterone sulfate concentrations in secondary adrenal insufficiency. J Clin Endocrinol Metab 1987;65:448-51.

21. Kannisto S, Korppi M, Remes K, et al. Serum dehydropepiandrosterone sulphate concentration as an indicator of adrenocortical suppression in asthmatic children treated with inhaled Steroids. J Clin Endocrinol Metab 2001;86:4908-12.

22. Sahiner UM, Cetinkaya S, Ozmen S, et al. Evaluation of adrenocortical function in 3-7 aged asthmatic children treated with moderate doses of fluticasone proprionate: reliability of dehydroepiandrosterone sulphate (DHEA-S) as a screening test. Allergol Immunopathol 2011;39:154-8.

23. Meikle AW, Kushnir MM, Rockwood AL, et al. Adrenal steroid concentration in children seven to seventeen years of age. J Pediatr Endocrinol Metab 2007;20:1281-91.

24. Auchus RJ. The physiology and biochemistry of adrenarche. In Ghizzoni L, Cappa M, Chrousos G, Loche S, Maghnie M, eds. Pediatric adrenal disease. Endocrine development. Vol 20. Basel: Karger, 2011:20-7.

25. Havelock JC, Auchus RJ, Rainey WE. The rise in adrenal androgen biosynthesis: adrenarche. Semin Reprod Med 2004;22:337-47.

26. Clark DJ, Clark RA, Lipworth BJ. Adrenal suppression with inhaled budesonide and fluticasone propionate given by large volume spacer to asthmatic children. Thorax 1996;51:941-3.

27. Mormede $\mathrm{P}$, Foury A, Barat $\mathrm{P}$, et al. Molecular genetics of hypothalamic-pituitary-adrenal axis activity and function. Ann N Y Acad Sci 2011;1220:127-36.

28. DeRijk RH. Single nucleotide polymorphisms related to HPA axis reactivity. Neuroimmunomodulation 2009;16:340-52.

29. Bertagna X, Coste J, Raux-Demay MC, et al. The combined corticotroph-releasing hormone/lysine vassopressin test discloses a corticotroph phenotype. J Clin Endocrinol Metab 1994;79:390-4.

30. Tsartsali L, Papadopoulos M, Lagona E, et al. Association of hypo-thalamic-pituitary-adrenal axis-related polymorphisms with stress in asthmatic children on inhaled corticosteroids. Neuroimmunomodulation 2012;19:88-95. 